\title{
Development of Cost effective Waste Water Treatment Model for Sustainable Utilization of House Hold Waste Water
}

\section{Narayana J*}

Department of Environmental Science, Kuvempu University, Jnana Sahyadri, Karnataka, India

*Corresponding Author: Narayana J, Department of Environmental Science, Kuvempu University, Jnana Sahyadri, Karnataka, India.

DOI: $10.31080 / A S A G .2020 .04 .0783$
Received: January 08, 2020

Published: January 28, 2020

(C) All rights are reserved by Narayana J.

\begin{abstract}
Waste water generated from house holds in urban areas is a huge loss of water resource. People never thought of reuse of their own water produced by the residents which contains organic and inorganic pollutants. The discharged waste water ultimately reach to the pristine water bodies and it turned to useless not only for potable and also for ecosystem. In this context, the proposed research work have been carried out to make use of every house hold water by using simple and cost effective treatment method maintained in each house with one treatment units connecting to waste water discharge points. Need based with simple method of treatment unit have been developed and it is evidenced that after treatment it can be reused for growing green vegetables and other purposes. This concept is thought of based on the eco friendly and sustainable waste water reuse and recycle method. The standard methods were followed and the results is discussed in detail.
\end{abstract}

Keywords: House Hold Waste Water; Water Treatment Unit; Sustainable Utilisation

\section{Introduction}

Water is one of the most important resources which human being has exploited than any other resources for sustenance of their life. Rising demands for water to supply of agriculture, industry and cities are leading to competition over the allocation of limited fresh water resources Logsdon G., [1]. The world's supply of fresh water is finite and is threatened by pollution. Waste water generated by local bodies are discharged either on land or into the surface of water. The land disposal causes ground water pollution whereas the disposal into surface water affects the aquatic life.

Waste water treatment is an environmental friendly process as a control of water pollution. Various waste water treatment methods are extensively followed for recycling of the water [2,3]. The household waste water can be reused for especially landscape irrigation, floor washing, car washing and toilet flushing Francisco Pedero [4]. To solve the problem of water pollution, waste water treatment is a method to remove the excess of impurities and to make use the water for domestic purposes. The most efficient and cost effective method of waste water treatment is slow sand filter method and knowledge about filtration mechanism still remains limited [5]. Similarly Jefferson., et al. [6] have studied technologies for domestic waste water recycling. The present study has been carried out to design a model for waste water treatment process in a laboratory scale for sustainable utilization of water.

\section{Materials and Methods}

Laboratory scale waste water treatment unit.

\section{Materials used}

- Waste water Samples were collected from the residential source near Kuvempu University area.

- $\quad$ Areca nut fibre: Areca nut husk were collected from the local areca gardens and washed, dried thoroughly and separated the fibers further air dried at $800 \mathrm{C}$ for 24-28 hour.

- Sand: $3 \mathrm{~kg}$ of sand with fine grains ranging from 0.10 to $0.25 \mathrm{~mm}$. has collected and it was washed thoroughly

- Coarse Gravel: About $1 \mathrm{~kg}$ of gravel were collected and washed thoroughly.

- Pebbles: About $1 \mathrm{~kg}$ of pebbles were collected and washed thoroughly.

- Maslin cloth: Maslin cloth used to remove coarse materials.

Low cost waste water treatment unit - A laboratory model

Two Transparent Fiber Cans with bottom tap were used to for waste water treatment process. Ten Liter Waste water samples have been collected in tank -1 and connected to the second tank for continuous supply for treatment purpose. In the Second tank treatment materials were filled in such a way that the bottom layer consists of $2 \mathrm{~kg}$ of coarse pebbles were placed to become a strong bed material and second layer one $\mathrm{kg}$ of small sized gravels were placed, similarly third layer $3 \mathrm{~kg}$ of coarse and fine sand were placed, subsequently $100 \mathrm{gms}$ of processed areca nut waste fiber were placed on the top layer and finally Maslin cloth was covered (Figure 1). 
Waste water from the first tank is being passed drop by drop to the treatment unit and collected treated water from the bottom tank and observed the effective reduction of impurities in the treatment unit. And subsequently noted the time. Total ten liter of waste water let into the treatment unit for about $24 \mathrm{hr}$. Out of ten liters of waste water we have received only nine liters. Interestingly one litre of water along with pollutants was settled in the treatment process. Further Treated water have been collected and used for physico-chemical analysis to assess the quality of treated water. The treatment unit is showing in figure 1.

The waste water samples have been collected at residential waste water discharge pipe sites located at shankaraghatta. In this present study, physical and chemical parameters of water samples were determined The samples collected were analyzed for important physical and chemical parameters such as PH, EC, free co2 Total Dissolved Solids, Total Hardness, $\mathrm{Ca}, \mathrm{Mg}$, were determined using standard procedures. (APHA, 1995). All the chemical constituents are expressed in mg/L (milligrams/liter) except $\mathrm{pH}$ and EC. To assess the quality of treated water, seed germination test have been employed. Ten pots were selected for experimental study. Regular use of vegetable seeds such as Arachis hypogaea, Vigna radiate, Macrotyloma uniflorum, Cicer arietinum, Brassica nigra Capsicum annuam, Trigonella foenum-graecum, Coriander satiuvm, Raphanus sativus, Amaranthus retroflexus were selected for germination study.

\section{Results and Discussion}

Physico-chemical analysis of waste water both before and after treatment results presented figure (1-XII) waste water before treatment observes slightly dark, whereas after treatment process the dark color completely removed through the layers of filtration bed. However slightly pink colour was observed in the collection tank it is due to areca nut fibers placed in the treatment tank for adsorption of impurities. In the present study $\mathrm{p}^{\mathrm{H}}$ shows alkaline to neutral condition before and after treatment (8-7.9 and 7.5-7.4).

Similarly Conductivity values of about $0.55 \mathrm{mS}$ and it reduced to $0.48 \mathrm{mS}$ after filtration and sample-2 shows about $0.51 \mathrm{mS}$ before treatment and it reduced to $0.48 \mathrm{mS}$ after treatment the reduction rate of conductivity is about $12.72 \%$ and $9.8 \%$ in sample-1 and sample- 2 respectively. Dissolved oxygen shows marked variation i.e. $3.2 \mathrm{mg} / \mathrm{L}$ to $8.0 \mathrm{mg} / \mathrm{L}$ in sample-1, i.e., $60 \%$ increase in sample-1. sample-2, DO level slightly increased from $3.0 \mathrm{mg} / \mathrm{L}$ to $7.7 \mathrm{mg} / \mathrm{L}$ i.e., $61.03 \%$. This indicates that this treatment process removed rich organic content. In the present study acidity also recorded before and after treatment sample- 1 shows $124 \mathrm{mg} / \mathrm{L}$ acidity then it reduced to $226 \mathrm{mg} / \mathrm{L}$ after treatment in sample-2 before treatment $182 \mathrm{mg} / \mathrm{L}$ and after treatment reduced to $39.2 \mathrm{mg} / \mathrm{L}$ there is an effective reduction in acidity i.e. $81 \%$ and $78.46 \%$ in sample- 1 and sample- 2 respectively. In the present study, alkalinity of the sample-1 shows $8 \mathrm{mg} / \mathrm{L}$, after treatment it reduced to $4 \mathrm{mg} / \mathrm{L}$. In sample-2 recorded $10 \mathrm{mg} / \mathrm{L}$ and it reduced to $4.8 \mathrm{mg} / \mathrm{L}$. There is an effective reduction in a alkalinity its about $50 \%$ and $52 \%$ in sample-1 and sample- 2 respectively. phosphate values recorded $0.19 \mathrm{mg} / \mathrm{L}$ (before treatment) and reduced to $0.15 \mathrm{mg} / \mathrm{L}$ (after treatment ) in

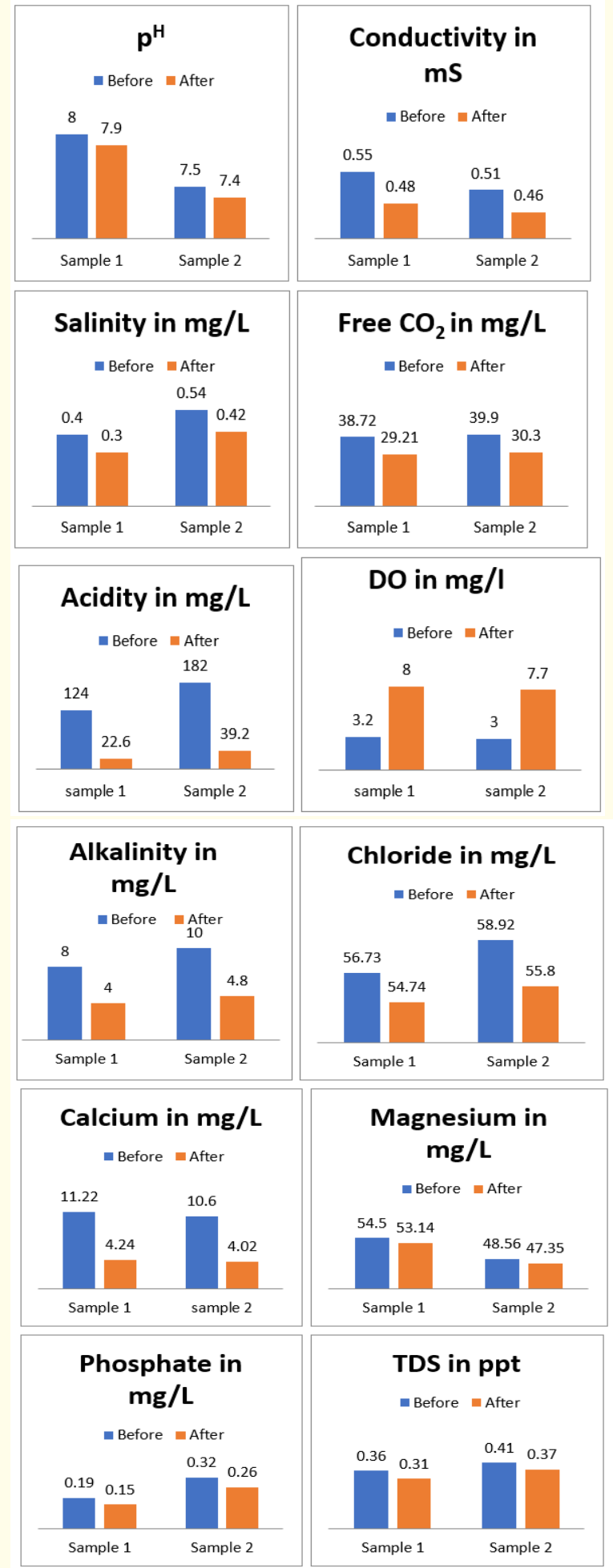

Figure 1: Physico-chemical analysis data shows variation before and After treatment (1-XII).

sample-1, and it reduced from $0.32 \mathrm{mg} / \mathrm{L}$ to $0.26 \mathrm{mg} / \mathrm{L}$ in sample-2, the reduction rate found about $21.05 \%$ and $18.75 \%$ in sample- 1 and sample- 2 respectively. Calcium values shows marked variation from $11.22 \mathrm{mg} / \mathrm{L}$ to $4.24 \mathrm{mg} / \mathrm{L}$ in sample- 1 and $10.6 \mathrm{mg} / \mathrm{L}$ to $4.02 \mathrm{mg} / \mathrm{L}$ in sample-2 there is an effective reduction in calcium it's about $62 \%$. Magnesium values shows $54.50 \mathrm{mg} / \mathrm{L}$ after treatment it was reduced to $53.14 \mathrm{mg} / \mathrm{L}$ in sample- 1 and in sample- 2 it reduces from $48.56 \mathrm{mg} / \mathrm{L}$ to $47.35 \mathrm{mg} / \mathrm{L}$. The reduction rate show very less i.e. about $2.49 \%$., chloride values reduced from $56.73 \mathrm{mg} / \mathrm{L}$ to 
$54.74 \mathrm{mg} / \mathrm{L}$ in sample-1 and $58.92 \mathrm{mg} / \mathrm{L}$ to $55.8 \mathrm{mg} / \mathrm{L}$ in sample-2 treatment of water is little effective in removing chloride content it's about $3.50 \%$ and $5.29 \%$ in sample- 1 and sample- 2 respectively. salinity of sample-1 is about $0.4 \mathrm{ppt}$ and it reduced to $0.3 \mathrm{ppt}$, in sample- 2 it is about $0.54 \mathrm{ppt}$ and it reduced to $0.42 \mathrm{ppt}$, the reduction of salinity in sample- 1 shows $25 \%$ and in sample- 2 shows $22.22 \%$.TDS values shows $0.36 \mathrm{ppt}$ and after treatment reduced to $0.31 \mathrm{ppt}$ (Sample-1) and sample-2 shows $0.41 \mathrm{ppt}$ and after treatment reduced to are reduced to $0.37 \mathrm{ppt}$. The rate of TDS reduction is about $13.88 \%$ and $9.7 \%$ in sample- 1 and sample- 2 respectively.

\section{Seed germination and growth rate}

Germination study experiments have been conducted to know the quality of waste water and also for sustainable utilization of treated waste water. The results shows that after 9 days growth rate (shoot and root length) was recorded. Among the seeds used for germination and growth rate, green gram, chick pea and ground nut seeds shows highest growth, i.e. $30 \mathrm{cms}, 29 \mathrm{cms}$ and $20 \mathrm{cms}$ of shoot length and $4.5 \mathrm{cms}, 9 \mathrm{cms}$ and $11 \mathrm{cms}$ of root length respectively. This indicates that treated water can be effectively utilized for growing green vegetables and pulses in garden area as well as backyard, and also on roof top of the buildings.

\begin{tabular}{|l|c|c|c|c|c|c|c|}
\hline \multirow{2}{*}{ Sl. No. } & \multirow{2}{*}{ Plant name } & \multicolumn{3}{|c|}{$\begin{array}{c}\text { Shoot length } \\
\text { (in cms) }\end{array}$} & \multicolumn{3}{c|}{$\begin{array}{c}\text { Root length } \\
\text { (in cms) }\end{array}$} \\
\cline { 3 - 8 } & & $\mathbf{1}$ & $\mathbf{2}$ & $\mathbf{3}$ & $\mathbf{1}$ & $\mathbf{2}$ & $\mathbf{3}$ \\
\hline 1 & Coriander & 10 & 11 & 13 & 4 & 4 & 4 \\
\hline 2 & Chilli & 6 & 7 & 7 & 2 & 2 & 2 \\
\hline 3 & Amaranth & 5 & 6 & 7 & 2 & 1 & 1 \\
\hline 4 & Radish & 16 & 17 & 21 & 7 & 4.5 & 2 \\
\hline 5 & Funu Greek & 10 & 12 & 12 & 4 & 4 & 5 \\
\hline 6 & Horse gram & 19 & 19 & 19 & 5.5 & 5.5 & 5.5 \\
\hline 7 & Ground nut & 18.5 & 19 & 20.5 & 10 & 10.3 & 11.5 \\
\hline 8 & Chick pea & 28 & 28 & 29 & 9 & 9 & 10 \\
\hline 9 & Mustard & 10 & 9.5 & 10.5 & 3 & 2.5 & 3 \\
\hline 10 & Green gram & 29.5 & 29 & 30 & 4.5 & 4 & 2.5 \\
\hline
\end{tabular}

Table 1: Plant growth (root and shoot length) recorded in treated water.

\section{Conclusion}

In the present study cost effective waste water treatment unit was developed in the laboratory as a pilot scale plant in order to know the efficiency of waste materials used for treatment process. It was concluded that areca nut husk, which is available abundant resource in local area that can be experimentally used to understand the efficiency of adsorption of waste impurities. Similarly small, and coarse pebbles and sand bed act as infiltration of waste impurities in water. The results shows that, increasing dissolved oxygen and Acidity, Alkalinity, Calcium, percentage shows reducing trend $60.515 \%, 79.73 \%, 51 \%$ and $62.14 \%$ respectively. Finally treated water have been used for germination study and growth rate also shows $100 \%$ The study concludes that house hold waste water can be effectively utilized in each and every house by following this lab scale cost effective treatment model to set up the small scale, low cost, cheap and simple treatment unit in order to control water pollution. Domestic wastewater recycling is still in its infancy and as such, there is a paucity of reliable information relating to both the nature of grey water and the range of recycling technologies available.

\section{Bibliography}

1. Logsdon G. "Slow sand filtration for small water systems". Journal of Environmental Engineering and Science 1 (2002): 339-348.

2. Ingole Sangita., et al. "Study of physico-chemical parameters of sewage water from some selected location on Amba Nalla, Amravati". Indian Journal of Applied 3.8 (2013): 377.

3. Dhote Jayashree., et al. "Treatment of sewage using dual Media filter and its Sustainable reuse". Indian Stream Research Journal (2013): 43-50.

4. Francisco Pedero. "Use of treated municipal waste water in irrigated agriculture". Agricultural Water Management 97.9 (2010): 1233-1241.

5. Ellis KV. "Slow sand filtration as technique for the tertiary treatment of municipal sewages". Water Research 21 (1987): 403-410.

6. Jefferson B. "Technologies for domestic waste water recycling". Urban Water 1.4 (2000): 285-292.

\section{Assets from publication with us}

- Prompt Acknowledgement after receiving the article

- Thorough Double blinded peer review

- Rapid Publication

- Issue of Publication Certificate

- High visibility of your Published work

Website: www.actascientific.com/

Submit Article: www.actascientific.com/submission.php Email us: editor@actascientific.com Contact us: +919182824667 